\title{
Employees' Attitude and Their Performance: A Study of Senior Staff of University of Cape Coast
}

\author{
Buah Soale, Alhassan Mbawin Akudugu \\ Bagabaga College of Education, Tamale, Ghana \\ Gbewaa College of Education, Pusiga, Bawku
}

\begin{abstract}
How employees feel and behave in an organisation is very important in determining how they will perform any assigned task. As such, employee attitude has been at the centre stage of human resource management strategies as a means to improving their performance and commitment to their job and by extension the performance of the organisation. In this regard, this study examined the causality between the attitude and job performance of senior staff of University of Cape Coast. Due to the large number of staff and demands of the research objectives, a quantitative approach was adopted using a descriptive research design. A sample size of 308 was derived from a population of 1,532 using Krejcie and Morgan (1970). Questionnaire was used to randomly collect data from 308 senior staff. SPSS was used to code and capture the data besides performing factors analysis on the challenges that impede management's ability to improve the attitude of senior staff. Smart PLS 3 was used to perform partial least square regression analysis on the link between attitude and performance of the staff. The results show that about $43 \%$ of changes in senior staff's job performance can be attributed to changes in their attitude. Also, the attitude of the senior staff can predict about $26 \%$ of how they will perform their job. Stimulating innovations and change, improving ethical behaviour and total quality management are the main challenges that impedes management's ability to improve the attitude of the senior staff in relation to their job performance. For policy implications management should also dedicate resources to mitigating jealousy among staff.
\end{abstract}

Keywords: Commitment, Employee attitude, Job Involvement, Job Satisfaction, Job Security, Performance

\section{Introduction}

Imparting knowledge, building the skills and competences of future leaders are the primary goals of tertiary institutions (Boice, Torrisi-Steele \& Boice, 2018; Datta, 2018). With the global demand for competent and skilled labour, tertiary institutions and organisations are devoting more resources to acquiring, training and maintaining skilled and competent employees as a strategy to creating a robust workforce (Madrigano, Chandra, Costigan \& Acosta, 2020). These calibre of skilled staff do not only bring innovations and creativity to tertiary institutions, they ensure a guaranteed competitive advantage besides internal discipline (Galsworth, 2017). This inevitable need for such a skilled staff conforms to the assertion that human capital is the most important resource of any organization (Sumption, 2017; Contigiani, Hsu \& Barankay, 2018). In support of this assertion, Nieves and Quintana (2018) explained that irrespective of the quality and quantity of machinery, procedures, polices and financial strength of any organisation, it is the human capital that can operate all these in a coordinated and synchronized manner to achieve a desired objective. For this to be possible, however, an organisations needs to have well motivated and dedicated staff.

This explanation is supported by the Herzberg and Maslow theories of motivation. Maslow (1943) is of the opinion that within every person, there exists a hierarchy of five needs. Each level of need must be satisfied before an individual pursues the next higher level of need. This means that once the basic level of need is reached, an employee may be encouraged to access the next level. Therefore, to be able to properly motivate 
an individual, attitude must be given outmost priority. To achieve this, Maslow argued that the physiological needs must be considered first as a means to eventually achieving self-actualization. Herzberg on the other hand argued that though these needs may influence the attitude of an employee, it may be subject to circumstances. Therefore, only by devising effective strategies to manage employees' attitude that management will be able to achieve the needed benefits of their talents and skills (Herzberg, 2017).

Furthermore, there are enough evidence (Hee \& Jing, 2018; Mohan \& Sudarsan, 2018; Ciobanu, Androniceanu \& Lazaroiu, 2019) to support the notion that managing employee attitude positively influence their job performance and by extension institutional performance. Similarly, Mohan and Sudarsan (2018) posit that if job performance is defined in terms of quantity and quality expected from an employee, then important determinants of employee attitude such a job satisfaction, job commitment, job involvement, task performance and contextual performance must be taken into account if management wants to achieve its goals and improve on job performance. Mohan and Sudarsan (2020) further explained that the need for such causality is as a result of the fact that attitudes are evaluative statements which may either be favorable concerning objects, people or events. Because they reflect how one feels about something. In the workplace, they reflect how an employee feels about his work, the work environment, resources, policies and procedures (Mohan and Sudarsan, 2020).

With a huge number of students to manage, train and graduate, tertiary institutions require an equally large number of staff of different categories with varied skills set to be able to fulfill their key objectives of imparting knowledge to students (Dixit \& Dean, 2020; Iwu, Chapano \& Twum-Darko, 2018). This makes job performance of the employees in tertiary institutions really important since that determines failure and success (Saputra, Sudiro \& Irawanto, 2018). Similarly, Shen and Zhang (2019) observed that managing employee attitude is the most important factor in improving job performance. By the same token, Masa'deh, Almajali, Alrowwad \& Obeidat (2019) argued that even the most skilled and talented employee might be prone to severe underperformance if his attitude in the workplace is lacking. The global rise in competition in every human discipline, the need to improve employee performance in tertiary institutions, particularly universities cannot be overrated (Abualoush, Obeidat, Tarhini, Masa'deh \& Al-Badi, 2018). The ubiquitous nature of advance technology has made the world a global village and smaller that anyone could imagine (Iwu et al., 2018).

This means that acquiring tertiary education does not necessarily mean physically attending an institution (Abualoush, Obeidat, Tarhini, Masa'deh \& Al-Badi, 2018). There are online institutions that offer diverse courses and training for anyone willing to learn. To further compound the rise in competition among universities in most developing countries like Ghana, tertiary institutions are springing up at a very rapid rate (Ohemeng, Amoako-Asiedu \& Darko, 2018). These institutions offer diverse courses and programmes in strategic ways that suit the requirements of different category of students (Ohemeng et al., 2018). Thus, with such competition at hand, it is important for management of Universities to fill their ranks with employees whose positive attitude of dedication and commitment lead them to high levels of effort and can excel even when they are not the most talented and skilled (Mensah, 2019). Research findings of Madrigano et al., (2020) revealed that organizations have grown increasingly aware of the significance of managing employee attitude and are investing more time and effort than ever before to creating the best attitude possible among their employees.

Sachane, Bezuidenhout and Botha (2018) on the other hand noted that employee attitudes are not only related to different aspects of human life but also, they are rooted in the mind-set and manifest in the behaviour of the employee. Empirical evidence from the work of Sathyanarayan and Lavanya (2018) shows that job satisfaction is a primary factor in employee attitude. However, it is worth distinguishing it from the broader category of organizational commitment. Boateng and Hsieh (2019) on the other hand established a direct link between job performance and employee morale. Therefore, if management shows a willingness to listen and adapt, every attitude itself can provide a significant boost to employee morale. Boateng and Hsieh further noted that when employees believe that management listens to their concerns, cares about them and willing to make some compromises, it goes a long way toward creating a positive atmosphere and positive attitudes amongst them. 
Based on the aforementioned review, it suffices to conclude that employee attitude is directly influenced by their job satisfaction, job involvement, job commitment, organizational justice, job security, motivation and many more. Further evidences (Perreira, Berta, Ginsburg, Barnsley \& Herbert, 2018; Rahim, Hassan, Amdan \& Munap, 2018; Charoensap, Virakul, Senasu \& Ayman, 2019) point to the fact that these tenets of attitude do not just affect job performance but positively influence each other as well. They also found that job satisfaction has a significant effect on job performance while Alahmad, Pierce, Carter and Robert (2018) established a direct effect of job satisfaction on job performance but it was not significant. Jain and Ansari (2020) on the other hand noted that employee attitude is positively related to political behaviour. Conversely, Fako, Nkhukhu-Orlando, Wilson, Forcheh and Linn (2018) noted a significant inverse relation between political behaviour and job satisfaction. Mikkelsen and Olsen (2019) for their part noted that job security significantly influences job performance and job commitment whilst Lambert, Qureshi, Frank, Klahm \& Smith (2018) also established a significant relationship between job involvement, job security and job performance.

The importance of managing employee attitude has be clearly noted in the aforementioned literature review. There are research evidences that indicate that employee attitude has an influence on the job performance. In this regard, this research sought to examine the Strategies University of Cape Coast (UCC) employ to manage employee attitude and how they impact on their job performance. The senior staff of UCC like that of any other well established tertiary institution is responsible for the operational level activities on the University as such their job performance directly determines the performance of the University. This means that the competence, effectiveness and efficiency of the university largely depend on how well the senior staff perform their daily tasks.

\section{Objectives of the Study}

i. To determine how the attitude of Senior staff of UCC influences their job performance

ii. To identify and assess the challenges to improving employee attitudes

\section{Conceptual Framework}

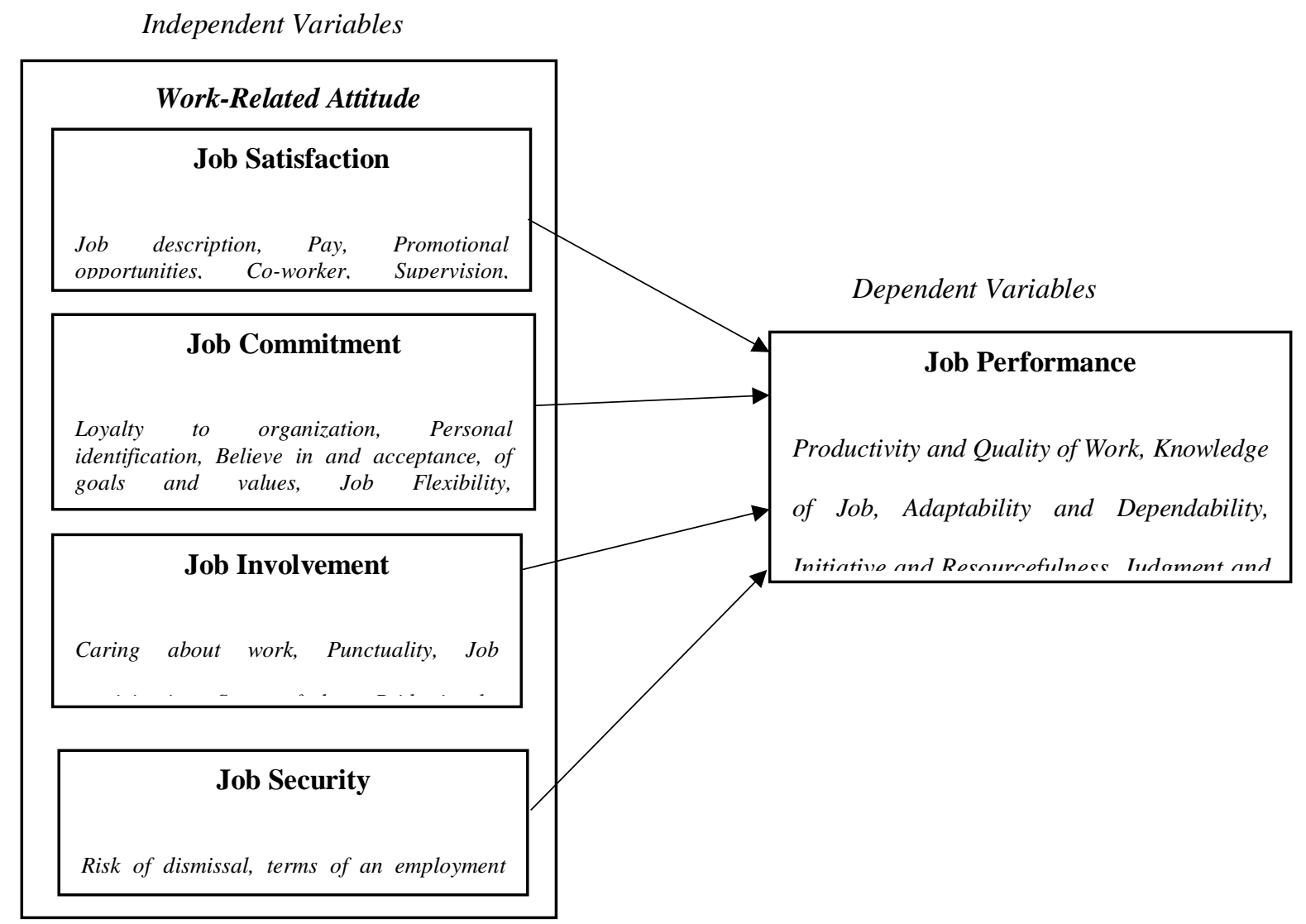

Figure 1: Conceptual Framework. Source: Authors' Construct, Buah \& Akudugu, 2020 


\section{Research Method}

Collecting data on work related attitudes and job performance of senior staff of UCC required tact. The data required for these constructs were latent and as such were measured using the Likert Scale. The staff were asked to indicate the extent to which factors influencing work related attitudes and job performance affected them. For the factors influencing work related attitudes, the staff were asked to indicate 1 as strongly agree, 2 as agree, 3 as not sure, 4 as disagree and 5 as strongly disagree. For job performance, the staff were asked to indicate 1 as Low, 2 as need supervision, 3 as average, 4 as indifferent, 5 as above average and 6 as excellent. Information from the human resource depart showed that as at 2019, there were a total of 1,539 senior staff in UCC. Therefore, using Krejcie and Morgan (1970), a total of 308 staff were sampled.

Questionnaire was used to randomly collect data from 308 senior staff of UCC. SPSS version 22 was used to code and capture the data. Missing value analysis was done to ensure the data was valid for further analysis. For the challenges to improving employee attitudes, factors analysis was used to reduce the data to the ones with the most significant effect (Bandalos \& Finney, 2018). SmartPLS3 was used to perform partial least square regression analysis on the link between work related attitudes and job performance (Benson \& Tippets, 2018).

\section{Results and Discussion}

It can be observed from figure 2 that collective bargaining agreement, job participation, organisational justices, salary and incentives and work conditions are the prominent factors influencing the attitude of senior staff of UCC. However, it can be observed that organisational justices and salary/incentives have the highest impact on the staff attitude. Also, from table 1, the Cronbach's Alpha shows that the five main attitude of the Senior staff are $76.5 \%$ reliable and account for $77 \%$ of all factors influencing the attitudes of senior staff of the university (rho_A = 0.77). Furthermore, since the AVE value is more than 0.5, it implies that the five primary attitudes of the senior staff correlates positively with each other. However, since the HTMT Value is less than 0.9, it implies that each of the five attitudes of the senior staff are distinct and do not linearly predict each other.

Similarly, with regard to job performance, it can be observed in figure 2 that the capability of the senior staff in doing their job rest on adaptability and dependability, initiatives and resourcefulness, judgment and policy compliance, knowledge of job, punctuality/quality of work and relations with coworkers. Out of these six job performance factors, it can be observed that relations with co-workers and knowledge of job were the least influential factors affecting job performance of the senior staff. Nonetheless, the Cronbach's Alpha in table 1 shows that the six job performance factors are $89.9 \%$ reliable and account for $90.4 \%$ of total job performance of the senior staff as indicated by the rho_A value. Also, since the AVE value is more than 0.5, it means that there is a direct association between the six factors indicating the job performance of the senior staff. Furthermore, since the HTMT value is less than 0.9, it implies that the six factors influencing job performance are unique and do not linearly predict each other.

Table 1: Quality Criteria of the Effect of Employee Attitude on Job Performance

\begin{tabular}{|l|c|c|}
\hline Statistics & Employee Attitude & Job Performance \\
\hline f Squared (Effect Size) & & 0.744 \\
\hline Fornell-Larcker Criterion (Discriminant & 0.719 & 0.816 \\
\cline { 2 - 3 } Validity) & 0.653 & 0.898 \\
\hline Cronbach's Alpha & 0.765 & 0.904 \\
\hline rho_A & 0.770 & 0.922 \\
\hline Composite Reliability & 0.842 & 0.666 \\
\hline Average Variance Extracted (AVE) & 0.517 & \\
\hline Heterotrait-Monotrait Ratio (HTMT) & 0.779 & 1.000 \\
\hline Inner VIF Values & & \\
\hline
\end{tabular}

Buah \& Akudugu, 2020 


\section{How the Attitude of Senior Staff of UCC Influences Their Job Performance}

The results in figure 2 shows that $42.7 \%$ of changes in the job performance of the senior staff can be attributed to changes in their attitude. Furthermore, a unit change in the attitude of the senior staff will cause a $65.3 \%$ change in their job performance.

The regression model is written as

Job performance $=0.427+0.653($ Employee Attitude $)$

Equation 1: Impact of Senior Staff Attitude on their Job Performance

The model means that if there are no changes in the attitude of the senior staff, their job performance will increase by 0.427 , however, a unit change in their attitude will result in a corresponding increase of 0.653 in their job performance. Similarly, the f-square effect size value in table 1 indicates that $75.4 \%$ of job performance of the senior staff can be explained by changes in their attitude. Thus, the attitude of the senior staff is very important in determining their job performance. Furthermore, the Fornell-Larcker criterion indicates that the attitude of the senior staff is $71.9 \%$ distinct from their job performance and as a result they do not linearly predict each other. Nonetheless, the composite reliability in table 1 also indicates that as a model, the attitude of the staff is $84.2 \%$ reliable whereas their job performance is $92.2 \%$ reliable as indicated in equation 1 . The inner variable inflation factor of 1 further rules out any signs of multicollinearity.

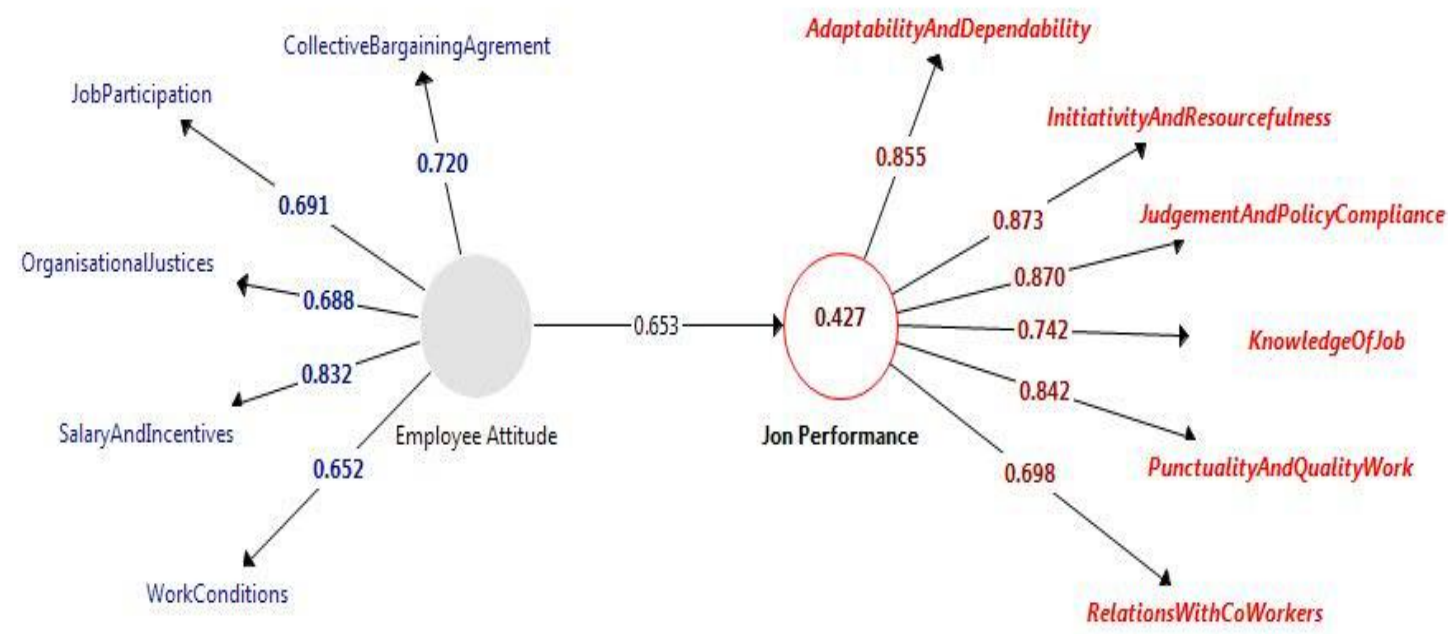

Figure 2: Effect of Employee Attitude on Job Performance. Source: Buah \& Akudugu, 2020

\section{Significance of the Attitude of Senior Staff in Explaining their Job Performance}

The results in Figure 3 is a bootstrapping analysis to indicate the significance of the senior staff attitude in explaining their job performance. The values indicated in the model are t-test of significance, the t-values indicate the differences measured in means/averages the constructs could have happened by chance. The rule of thumb is that as long as the t-value is greater than or equal to 2 , the effect is deemed significant. It thus suffices to conclude that the attitude of senior staff of UCC significantly explains their job performance. 


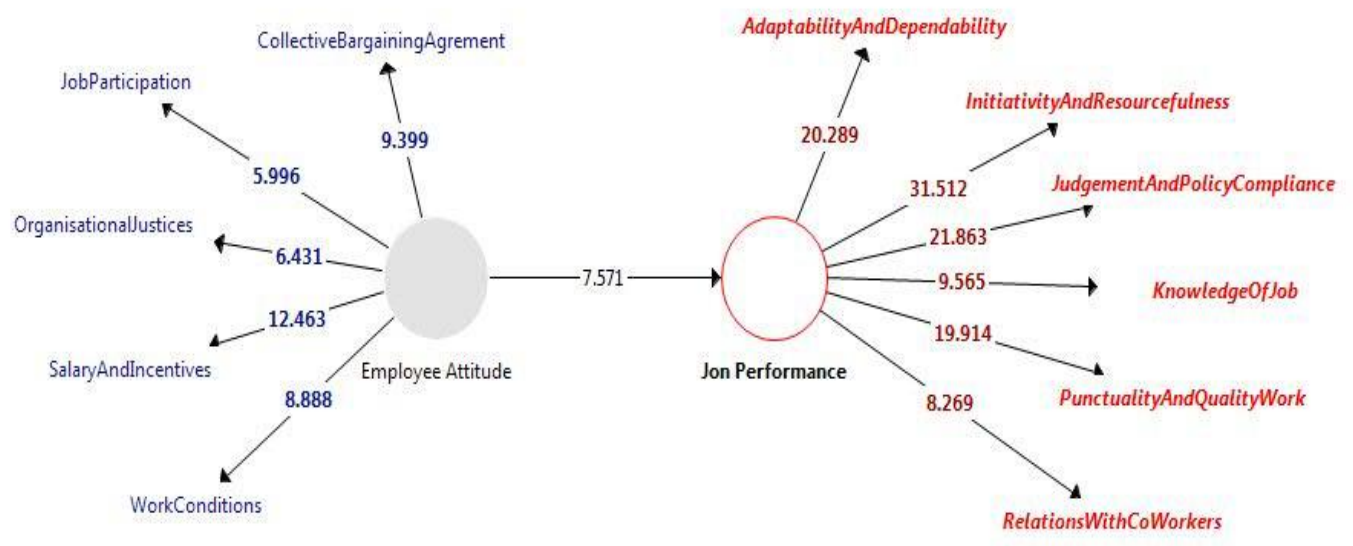

Figure 3: Significance of Senior Staff Attitude in Explaining Job Performance. Source: Buah \& Akudugu, 2020

\section{The extent to which the Attitude of the Senior Staff predicts their Job Performance}

The results in figure 4 show that $25.8 \%$ of changes in the job performance of the senior staff of UCC can be predicted by changes in their attitude.

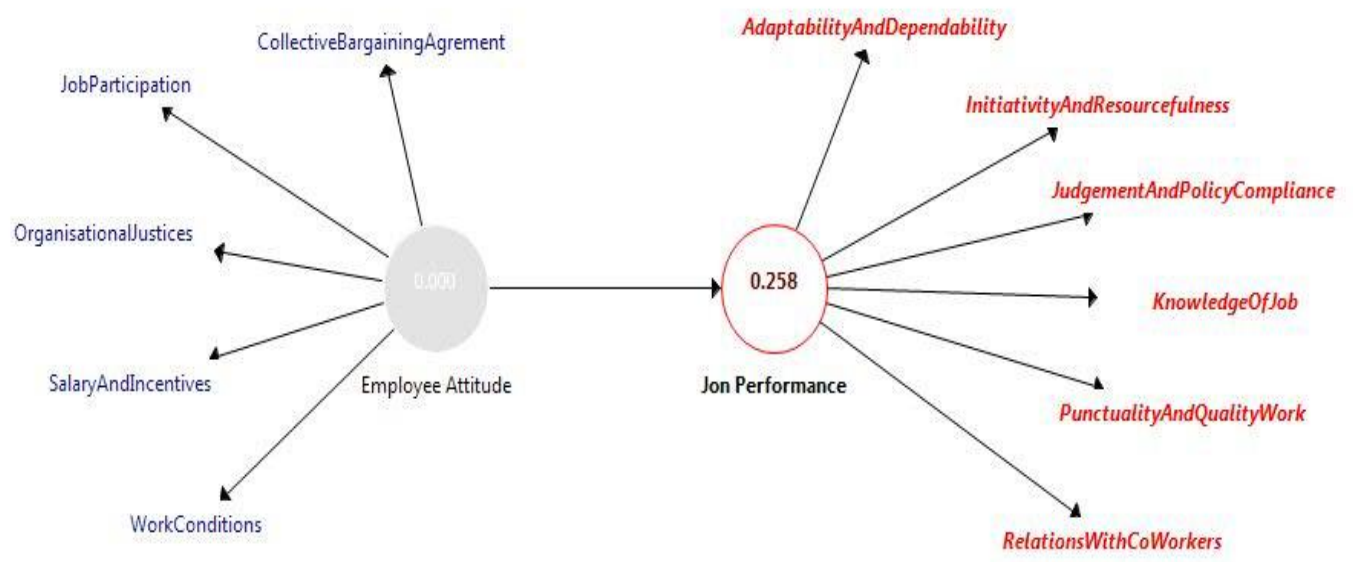

Figure 4: Predictive Relevance of Staff Attitude on their Job Performance. Source: Buah \& Akudugu, 2020

\section{The Challenges to Improving Employee Attitudes}

Evidence from table 2 shows that there are three primary challenges that impede management of UCC ability to improve the attitude of the senior staff. By contrasting it with the results in table 3, it can be observed that stimulating innovations and change, improving ethical behaviour and total quality management are the main challenges that impede management's ability to improve the attitude of the senior staff in relation to their job performance. The three factors account for about $31 \%$ of variations in the challenges to improving employee attitude.

The second category of challenges is constituted by improving people's skills and poor working conditions which account for about $24 \%$ of the variations in the challenges to improve the attitude of senior staff. Finally, it can be observed from table 2 that jealousy alone forms the third category of challenges that hinder improvement in the attitude of the senior staff. Table 4 shows that it accounts for about $15 \%$ of variations in the challenges to improving the attitude of the senior staff.

Furthermore, the KMO value in table 3 confirms that $62.3 \%$ of variations in the challenges to improving the attitude of senior staff of UCC can be attitude to variation in the three prominent categories of challenges in table 2. Also, the Bartlett's Test of Sphericity with an approx. Chi-Square value of 135.297 and Sig value of 0.0 indicates there are significant variations in the three categories of challenges. This means that they each exhibit an independent effect on the job performance of the senior staff.

Table 2: Challenges to improving Employee Attitude 


\begin{tabular}{|l|c|c|c|}
\hline \multirow{2}{*}{ Factors } & \multicolumn{3}{|c|}{ Component } \\
\cline { 2 - 4 } & 1 & 2 & 3 \\
\hline Stimulating Innovations and Change & 0.813 & & \\
\hline Improving Ethical Behaviour & 0.794 & & \\
\hline Total Quality Management & 0.744 & & \\
\hline Improving People's Skills & & 0.885 & \\
\hline Poor working conditions & & 0.700 & \\
\hline Jealousy Among Employees & & & 0.858 \\
\hline
\end{tabular}

Source: Buah \& Akudugu, 2020

Table 3: KMO and Bartlett's Test

\begin{tabular}{|l|l|r|}
\hline \multicolumn{2}{|c|}{ Kaiser-Meyer-Olkin Measure of Sampling Adequacy. } & 0.625 \\
\hline $\begin{array}{l}\text { Bartlett's Test of } \\
\text { Sphericity }\end{array}$ & Approx. Chi-Square & 135.29 \\
& & 7 \\
\cline { 3 - 4 } & df & 21 \\
\cline { 2 - 3 } & Sig. & 0.0 \\
\hline
\end{tabular}

Source: Buah \& Akudugu 2020

Table 4: Total Variance Explained

\begin{tabular}{|c|c|c|c|c|c|c|c|c|c|}
\hline \multirow[b]{2}{*}{ 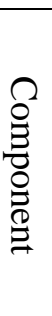 } & \multicolumn{3}{|c|}{ Initial Eigenvalues } & \multicolumn{3}{|c|}{$\begin{array}{c}\text { Extraction Sums of Squared } \\
\text { Loadings }\end{array}$} & \multicolumn{3}{|c|}{$\begin{array}{c}\text { Rotation Sums of Squared } \\
\text { Loadings }\end{array}$} \\
\hline & $\begin{array}{l}\mathrm{T} \\
\mathrm{O} \\
\mathrm{t} \\
\mathrm{a} \\
\mathrm{l}\end{array}$ & $\begin{array}{c}\% \text { of } \\
\text { Varianc } \\
\text { e }\end{array}$ & $\begin{array}{l}\text { Cumulat } \\
\text { ive } \%\end{array}$ & Total & $\begin{array}{c}\% \text { of } \\
\text { Varianc } \\
\mathrm{e}\end{array}$ & $\begin{array}{l}\text { Cumulati } \\
\text { ve } \%\end{array}$ & Total & $\begin{array}{c}\text { \% of } \\
\text { Varianc } \\
\mathrm{e}\end{array}$ & $\begin{array}{l}\text { Cumulati } \\
\text { ve } \%\end{array}$ \\
\hline 1 & $\begin{array}{l}2 \\
4 \\
4 \\
9 \\
8\end{array}$ & 35.683 & 35.683 & 2.498 & 35.683 & 35.683 & $\begin{array}{c}2.16 \\
3\end{array}$ & 30.907 & 30.907 \\
\hline 2 & $\begin{array}{l}1 \\
3 \\
3 \\
7\end{array}$ & 19.094 & 54.777 & 1.337 & 19.094 & 54.777 & $\begin{array}{c}1.66 \\
4\end{array}$ & 23.769 & 54.676 \\
\hline 3 & $\begin{array}{l}1 \\
0 \\
0 \\
7 \\
2\end{array}$ & 15.318 & 70.095 & 1.072 & 15.318 & 70.095 & $\begin{array}{c}1.07 \\
9\end{array}$ & 15.419 & 70.095 \\
\hline 4 & $\begin{array}{l}. \\
7 \\
4 \\
8 \\
\end{array}$ & 10.686 & 80.782 & & & & & & \\
\hline 5 & $\begin{array}{l}5 \\
5 \\
6 \\
4\end{array}$ & 8.057 & 88.839 & & & & & & \\
\hline 6 & $\dot{4}$ & 6.877 & 95.715 & & & & & & \\
\hline
\end{tabular}




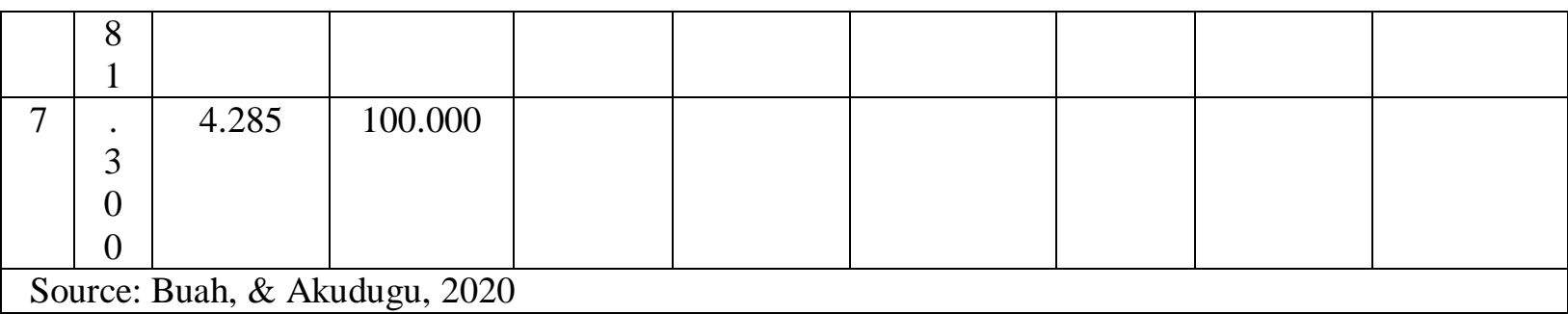

\section{Conclusion}

Based on the results of the analyses, it is obvious that the attitude of the senior staff of UCC is very important in determining their job performance and can equally predict the extent to which they will perform their job well. Furthermore, it can be observed that jealousy is a very significant hindrance to improving the attitude of the senior staff.

\section{Implication for Human Resource Management}

For policy implications, management should dedicate more resources to improving the attitude of senior staff in terms of job satisfaction, job commitment, job security and job involvement as they significantly determine the performance of staff and by extension the performance of the institution. Also, though stimulating innovations and change, improving ethical behaviour and total quality management are the main challenges impeding improvement to the staff attitude and as such must attract the lion share of resources, evidence from the analyses suggest that management should give significant attention to jealousy among staff as it defines the limits of co-worker relations.

\section{References}

[1] Abualoush, S. H., Obeidat, A. M., Tarhini, A., Masa'deh, R. E., \& Al-Badi, A. (2018). The role of employees' empowerment as an intermediary variable between knowledge management and information systems on employees' performance. VINE Journal of Information and Knowledge Management Systems, 48(2), 217-237.

[2] Alahmad, R., Pierce, C., Carter, M., \& Robert, L. (2018). The impact of enterprise social media identity on job performance and job satisfaction.

[3] Bandalos, D. L., \& Finney, S. J. (2018). Factor analysis: Exploratory and confirmatory. In The reviewer's guide to quantitative methods in the social sciences (pp. 98-122). Routledge.

[4] Benson, J., \& Tippets, E. (2018). Confirmatory factor analysis of the Test Anxiety Inventory. In Cross cultural anxiety (pp. 149-156). Taylor \& Francis.

[5] Boateng, F. D., \& Hsieh, M. L. (2019). Explaining Job Satisfaction and Commitment Among Prison Officers: The Role of Organizational Justice. The Prison Journal, 99(2), 172-193.

[6] Boice, W., Torrisi-Steele, G., \& Boice, G. (2018). Leading into the future. Strategic Leadership, 279.

[7] Charoensap, A., Virakul, B., Senasu, K., \& Ayman, R. (2019). Effect of Ethical Leadership and Interactional Justice on Employee Work Attitudes. Journal of Leadership Studies, 12(4), 7-26.

[8] Ciobanu, A., Androniceanu, A., \& Lazaroiu, G. (2019). An integrated psycho-sociological perspective on public employees' motivation and performance. Frontiers in psychology, 10.

[9] Contigiani, A., Hsu, D. H., \& Barankay, I. (2018). Trade secrets and innovation: Evidence from the "inevitable disclosure" doctrine. Strategic Management Journal, 39(11), 2921-2942.

[10] Datta, P. P. (2018). Developing competencies to lead innovation in Indian manufacturing: an education model. International Journal of Innovation Science, 10(4), 475-494.

[11] Dixit, S., \& Dean, A. (2020). The Impact of Talent Management on Job Satisfaction and Employee Performance in Public Sector Banks of Rajasthan. International Journal of Creative Research Thoughts, 6(1), 425-435.

[12] Fako, T. T., Nkhukhu-Orlando, E., Wilson, D. R., Forcheh, N., \& Linn, J. G. (2018). Factors associated with organizational commitment of academic employees in Botswana. International Journal of Educational Administration and Policy Studies, 10(6), 56-64.

[13] Galsworth, G. D. (2017). Visual Workplace Visual Thinking: Creating Enterprise Excellence Through the Technologies of the Visual Workplace. Productivity Press.

[14] Hee, O. C., \& Jing, K. R. (2018). The Influence of human resource management practices on employee performance in the manufacturing sector in Malaysia. International Journal of Human Resource Studies, 8(2), 129-147. 
[15] Herzberg, F. (1971). The motivation-hygiene theory. Work and the nature of man, 4.

[16] Herzberg, F. (2017). Motivation to work. Routledge.

[17] Iwu, C. G., Chapano, M., \& Twum-Darko, M. (2018). The impact of high performance work practices on project performance. A case study of construction companies in South Africa. Acta Universitatis Danubius. Economica, 14(1).

[18] Jain, L., \& Ansari, A. A. (2020). Effect of Perception for Organisational Politics on Employee Engagement with Personality Traits as Moderating Factors. The South East Asian Journal of Management.

[19] Lambert, E. G., Qureshi, H., Frank, J., Klahm, C., \& Smith, B. (2018). Job stress, job involvement, job satisfaction, and organizational commitment and their associations with job burnout among Indian police officers: A research note. Journal of Police and Criminal Psychology, 33(2), 85-99.

[20] Madrigano, J., Chandra, A., Costigan, T., \& Acosta, J. D. (2020). Beyond disaster preparedness: building a resilience-oriented workforce for the future. International journal of environmental research and public health, 14(12), 1563.

[21] Masa'deh, R. E., Almajali, D. A., Alrowwad, A. A., \& Obeidat, B. (2019). The Role Of Knowledge Management Infrastructure In Enhancing Job Satisfaction: A Developing Country Perspective. Interdisciplinary Journal of Information, Knowledge \& Management, 14.

[22] Maslow, A. H. (1943). A theory of human motivation. Psychological review, 50(4), 370.

[23] Mensah, J. K. (2019). Talent management and employee outcomes: A psychological contract fulfilment perspective. Public Organization Review, 19(3), 325-344.

[24] Mikkelsen, A., \& Olsen, E. (2019). The influence of change-oriented leadership on work performance and job satisfaction in hospitals-the mediating roles of learning demands and job involvement. Leadership in Health Services, 32(1), 37-53.

[25] Mohan, D., \& Sudarsan, N. (2020). Studies on Assessment of Parameters Influencing Employee Performance: A Review. IJAME.

[26] Mohan, D., \& Sudarsan, N. (2018). Studies on Assessment of Parameters Influencing Employee Performance: A Review. IJAME.

[27] Nieves, J., \& Quintana, A. (2018). Human resource practices and innovation in the hotel industry: The mediating role of human capital. Tourism and Hospitality Research, 18(1), 72-83.

[28] Ohemeng, F. L., Amoako-Asiedu, E., \& Obuobisa Darko, T. (2018). The relationship between leadership style and employee performance: An exploratory study of the Ghanaian public service. International Journal of Public Leadership, 14(4), 274-296.

[29] Perreira, T., Berta, W., Ginsburg, L., Barnsley, J., \& Herbert, M. (2018). Insights into nurses' work: Exploring relationships among work attitudes and work-related behaviors. Health care management review, 43(4), 315-327.

[30] Rahim, N. A. A., Hassan, L. A., Amdan, S., \& Munap, R. (2018). The Moderating Role of Organizational Citizenship Behavior on the Relationship between Organizational Justice and Job Satisfaction. International Journal of Arts \& Sciences, 11(1), 467-477.

[31] Sachane, M., Bezuidenhout, A., \& Botha, C. (2018). Factors that influence employee perceptions about performance management at Statistics South Africa. SA Journal of Human Resource Management, 16(1), 1-8.

[32] Saputra, P., Sudiro, A., \& Irawanto, D. W. (2018). Job satisfaction in compensation, environment, discipline, and performance: evidence from Indonesia higher education. Management and Economics Journal (MEC-J), 217-236.

[33] Sathyanarayan, D. K., \& Lavanya, D. B. L. (2018). Effect of Organizational Commitment, Motivation, Attitude towards Work on Job Satisfaction, Job Performance and Turnover IntentionllVUCA Perspective. Journal of Management, 5(4).

[34] Shen, J., \& Zhang, H. (2019). Socially responsible human resource management and employee support for external CSR: roles of organizational CSR climate and perceived CSR directed toward employees. Journal of Business Ethics, 156(3), 875-888.

[35] Sumption, M. (2017). Labour immigration after Brexit: questions and trade-offs in designing a work permit system for EU citizens. Oxford Review of Economic Policy, 33(suppl_1), S45-S53. 